\title{
From invention to industry from a social movement perspective: the emergence of the $3 \mathrm{D}$ printing industry
}

\author{
Christian Lechner ${ }^{*}$ (D) and Abeer Pervaiz
}

\author{
* Correspondence: christian. \\ lechner@unibz.it \\ Free University of Bolzano, School \\ of Economics and Management, \\ Piazza Università 1, 39100 Bolzano, \\ Italy
}

\begin{abstract}
In the entrepreneurship literature, the phenomenon of industry emergence has been largely investigated from an institutional perspective. Appropriate institutions would allow then a group of individual entrepreneurs ("the heroes") to create an industry through innovative ventures. New ventures create new industries and firm entry, survival, and exit drive industry evolution. Our research, however, explores what creates the favorable set of circumstances for new ventures to emerge and focuses on the pre-emergence phase and we propose that the patterns of emergence resemble those of social movements. Through an actor perspective, this research highlights the existence of diverse actors, not necessarily entrepreneurs, who are necessary to trigger a collective action during the pre-emergence phase of industries. This research is also distinct from entrepreneurial ecosystems as its development already requires some successful entrepreneurial action. The 3D printing industry was chosen as a single longitudinal case study, where the actors are the embedded units of analysis. The findings of the study lead to the identification of three aggregate dimensions- "Social Movement Composition," Temporal Engagement," and "Coalitions Development"—that were prevalent during the pre-emergence phase of the 3D printing industry. Our propositions emphasize the importance of large collective action and the role of multiple actors in order to create the conditions for, first, firm emergence and, the second, to the process of industry emergence.
\end{abstract}

Keywords: Industry emergence, Social movements, Entrepreneurship, 3D printing industry

\section{Introduction}

Most industries began with some sort of invention, such as the telephone, light bulb, radio, television, and so on. While the credit of the invention goes to the inventors, the credit of industry creation goes to the entrepreneurs founding new firms. Research that investigates patterns of firm entry, survival, and exit to understand emergence and evolution of industries make an important contribution (Klepper, 1997) but cannot explain what creates a favorable set of circumstances for these firms to emerge in the first place. However, this research gives one important insight: the idea of redundancy.

(c) The Author(s). 2020 Open Access This article is licensed under a Creative Commons Attribution 4.0 International License, which permits use, sharing, adaptation, distribution and reproduction in any medium or format, as long as you give appropriate credit to the original author(s) and the source, provide a link to the Creative Commons licence, and indicate if changes were made. The images or other third party material in this article are included in the article's Creative Commons licence, unless indicated otherwise in a credit line to the material. If material is not included in the article's Creative Commons licence and your intended use is not permitted by statutory regulation or exceeds the permitted use, you will need to obtain permission directly from the copyright holder. To view a copy of this licence, visit http://creativecommons.org/licenses/by/4.0/. 
Redundancy means that more firms need to emerge in order to create a few relevant and successful firms. Entrepreneurial agency understands the outcome of entrepreneurial action as the interaction between individuals and their environment (Goss \& SadlerSmith, 2018). If we combine the insight of redundancy with the actor-based approach of entrepreneurial agency, then there is an utmost need to identify not only how an industry emerges, but what exactly happens before it emerges (pre-emergence)? What actors are involved? When are they involved? How are they involved? Though the questions asked in this study are broad, they tend to explore knowledge and understanding of the phenomenon of industry emergence and its relation to entrepreneurship at a deeper level. Indeed, within management and organization literature, what happens between the invention and the formation of an industry is not well understood and the question "how industries emerge?" is still ambiguous. Research tends to favor institutional explanations or prototypical actors that fulfill mechanically specific functions.

Even the concept of entrepreneurial ecosystems, despite its emphasis on embedding entrepreneurship as a social process, is unable to bring clarity when it comes to which actors or how many actors are involved in a particular ecosystem as actors in ecosystems are reduced to prototypical functions such as venture capitalist and business angel. (Stam \& Spigel, 2017). According to O’Shea, Farny, \& Hakala (2019), studies related to entrepreneurial ecosystems are mostly "typological" and "theoretical" in nature and currently fail to properly integrate the entrepreneurial process in further development of the concept, favoring a view of efficient institutions rather than redundant actors. Moreover, entrepreneurial ecosystems appear to require already some successful entrepreneurial action as role models in order to develop fully (Isenberg, 2011). Cavallo, Ghezzi, \& Balocco (2018) emphasize that future research on entrepreneurial ecosystems should make an effort to try and involve a wider range of actors that have a significant role within the entrepreneurial ecosystem lifecycle- "i.e. its creation, growth, stability or sustainability - in order to advance the entrepreneurial ecosystem research along the right lines" (p.22).

However, some scholars have identified the importance of several diverse actors, besides the entrepreneur, that may be responsible for industry creation, reinforcing the idea of redundancy (e.g., Eliasson, 2000; Mezias \& Kuperman, 2001; Sine \& David, 2002; Van de Ven, 1993a, 1993b). This in turn has led to studies where collective action and social movements $(\mathrm{SM})$ are being implemented to understand how industries emerge (e.g., Barnett, 2006; Carlos, Sine, Lee, \& Haveman, 2014; Lounsbury, Ventresca, \& Hirsch, 2003; Pacheco, York, \& Hargrave, 2014; Pacheco \& Dean, 2015; Schneiberg \& Lounsbury, 2008; Soule, 2012; Walker, 2012; Weber \& King, 2014). Most SM studies related to industry emergence are based on institutional perspectives rather than actor perspectives. Therefore, our research objective is to understand how the idea of redundancy can be applied to an actor perspective of industry emergence. From an actor perspective, participation of aligned actors is the key for understanding collective action (Oliver \& Marwell, 1988). This leads us to the research question of how necessary participation for industry emergence is enabled and why actors get and stay involved.

Our study argues that industry emergence is a social process that is embedded with diverse actors, entrepreneurs, communities, institutions, and organizations, allowing also for redundancy of actors. Our objective is to develop a conceptual framework that 
can act as a complementary method to understand the emergence of an industry from its inception. Our objective is first, to complement the arguments of the "hero entrepreneur" (Reynolds, 1991) and efficient institutions (Sine \& David, 2010) with the possibility of other diverse actors that may be responsible for the creation of an industry. The concept of SM aids in understanding this process because, first, it helps in the identification of actors and, second, its wider approach tends to involve the whole society as a collective action rather than just the entrepreneur(s) and/or institutions. Furthermore, emphasis is placed more on the pre-emergence phase of the industry which is somehow left untouched in management literature (Forbes \& Kirsch, 2011; Gustafsson, Jääskeläinen, Maula, \& Uotila, 2016). Given this perspective and research objectives, the $3 \mathrm{D}$ printing industry is chosen as a single case study and the participants are the actors as the embedded unit of analysis.

The study begins with a theoretical foundation of the research followed by the research methodology section. After the data analysis, the findings are presented followed by the discussion section. Finally, it proceeds towards the limitations, future research, and conclusion.

\section{Theoretical background}

The general focus of entrepreneurial scholars has been on either individual entrepreneurial behavior or the activity of entrepreneurial (new) firms (Reynolds, 1991). Recent studies on entrepreneurship have started seeing entrepreneurs from a sociological angle distributed among several actors (Jennings, Greenwood, Lounsbury, \& Suddaby, 2013). This portrays entrepreneurship to be distributed among several actors where switching back and forth as projects evolve seems to be the mode of action (Delbridge \& Edwards, 2008; Lounsbury \& Crumley, 2007). These studies tend to decentralize the individual entrepreneur by emphasizing the entrepreneurial phenomenon as a broader field that involves "temporal," "spatial," "social, organizational," and "market dimensions" (Zahra, 2007; Zahra, Wright, \& Abdelgawad, 2014).

Entrepreneurship can be viewed as an interaction among individuals, social communities, and the whole of society (Welter, 2011). Yet, in prior studies, the focus has been on the role of the entrepreneurs as firm founders, "who are considered as leaders in the creation of new industries" (Mezias \& Kuperman, 2001, p.210). However, entrepreneurs' embeddedness in communities extend this view: communities create more openness (West \& Kuk, 2016) and spaces for sharing ideas (Felin and Zenger 2009). The case of user entrepreneurs emphasizes that communities emerge where like-minded individuals come together to share and engage in similar activities and practices related to products and technologies (Frederiksen, Dahlander and Autio 2008). Industries, such as the $3 \mathrm{D}$ printing industry, are conducive to openness and user entrepreneurship as they provide entrepreneurial opportunities at various points along the industry's value chain (Holzmann, Soomro, Aqeel, \& Schwarz, 2017). The concept of user entrepreneurship and openness within community are similar to the concepts of SM, in the sense that diverse actors having similar goals form together a community that allows sharing of ideas, that eventually allows growth of the movement, or in this case the industry.

Management scholars and sociologists have observed the contentious nature of the social construction of markets and recognized that social forces play an important role 
in the emergence of industries (Pacheco et al., 2014). According to Weber and King (2014), through SM, organizational scholars were able to explain bottom-up purposeful change without depending on individualistic models of behavior. Furthermore, the concepts and perspective of SM have been successfully applied towards understanding the emergence and transformation of organizational fields, markets, and industries as contested forms of collective action.

In technology-intensive industries, fragmented interests across industry participants often complicate the collective action process. Such competition can hinder collective action as industry participants promote their own interests and fail to advance the interests of the overall industry in obtaining legitimacy (Aldrich \& Fiol, 1994; Barnett, 2006; Van de Ven \& Garud, 1994). Oliver and Marwell (1988) highlight that the real issue of collective action lies in realizing the existence of a social mechanism that allows having enough people that share similar interests and resources over which they act upon. If heterogeneity exists among a group that can make large contributions, and if the members are connected to one another socially in such a way that they act together, then the possibility of collective action within larger groups is more likely to take place.

According to Van de Ven (1993a, 1993b) industry emergence depends on the ability of individuals and actors to transform into nodes in value chains and industrial infrastructure, while combining the interests of their newly formed industry with the interests of other players. SM theory provides insight into the process where actors can translate their shared interests through collective action (Weber \& King, 2014). This leads to new collective identities and solidarity that creates new industries of organizational forms (Rao, Monin, \& Durand, 2003; Sine \& Lee, 2009; Weber, Heinze, \& DeSoucey, 2008). Most studies have acknowledged and implemented the concepts of SMs successfully in understanding the emergence of organizational fields, markets, and industries (Barnett, 2006; Carlos et al., 2014; Lounsbury et al., 2003; Pacheco et al., 2014; Rao, 1998; Rao, Morrill, \& Zald, 2000; Schneiberg, King, \& Smith, 2008; Sine \& Lee, 2009; Walker, 2012; Soule, 2012; Weber \& King, 2014). However, the implementation of SMs in understanding the emergence of industries has been limited to an institutional and entrepreneurial perspective and that too on already established industries such as the US recycling industry, American insurance, dairy, grain, and windmill industries. What remains still an unanswered realm is what happens in the earlier history of the industry and how can SM play its role? Our research tends to ask the following: (1) How does an industry emerge through collective action of actors from diverse backgrounds (which also includes entrepreneurs, communities, organizations, firms, institutions)? And (2) are there any predictable patterns in the industry emergence process?

\section{Research approach and methods}

A qualitative approach is believed to be an effective method for this study as both the research questions and the chosen industry have human and social elements which allows the flexibility to ask "how and why" questions (Agee, 2009). According to Pratt (2009) the qualitative approach is an appropriate method to ask "how" questions rather than "how many" which allows understanding the world from the viewpoint of the subject being studied (i.e., informants) and for examining and articulating processes. In our case, the limitations of institutional approaches and the view of the hero entrepreneur, 
as well as entrepreneurial ecosystems, lead us to the exploration of collective action for industry emergence: This in an under-researched topic, where we lack sufficient knowledge for the development of hypotheses. Grounded theory allowed deeper analysis and space for theory to emerge from the data set. This will be further explained in detail.

\section{Context and framework}

The specific industry chosen, to explore its emergence by looking at the actors involved, is the 3D printing industry. A single case study design with embedded units (where the embedded units are the actors) was chosen because of (a) the existence of how and why questions (Yin, 2003) and (b) the uniqueness of the phenomenon being investigated. The $3 \mathrm{D}$ printing industry provides a distinctive research setting, having only been recognized as an industry from the past few years. Even though the technology was recognized in the late 70s, it is still in a relatively emerging stage as an industry. Its status also helps in setting this study apart from earlier studies that are based mostly on already established industries. Furthermore, it also gives a unique edge in initiating the study from an actor perspective rather than from an institutional and/or entrepreneurial perspective. Recent studies such as by West and Kuk (2016) and Holzmann et al. (2017) have studied 3D printing from a community perspective, but already at the later stage of startups and the in the development of effective business models. While there is an abundance of studies on the emergence of 3D printing from a technology perspective in the field of engineering and robotics, we have focus on collective action in the pre-emergence phase of industries. Since there is limited empirical evidence related to the emergence of 3D printing, our study expands on these insights by examining the actor perspectives during the pre-emergence phase, thereby providing a better understanding of the emergence process of how diverse actors come together, along with entrepreneurs in order to enable industry emergence.

\section{Case study background}

The late 1980s marked the earliest 3D printing technologies, they were more known as Rapid Prototyping technologies. These processes were considered originally to be fast and most cost-effective methods to create prototypes for product development within an industry (3D Printing, 2014). Bourell, Beaman, Leu, and Rosen (2009) referred this technology as additive manufacturing where the late 1980s and early 1990s saw a number of additive manufacturing processes to emerge. On March 9, 1983, an inventor known as Charles Hull used a computer-controlled, ultra-violet laser to trace out and solidify a single layer of an object on the surface of a tank of liquid photopolymer. Using this process he was able to create a small blue plastic teacup. Hull had thus invented 3D printing. On March 11, 1986, Hull managed to get the US patent for his Apparatus for production of Three-dimensional Objects by Stereolithography. He also co-founded the company 3D systems Corporation where he along with his team also created the STL file format that makes computer-aided design software data to be used for 3D printers. 3D Systems also sold its first commercial 3D printer or Stereolithography Apparatus, SLA-250 in 1988 (Barnett, 2014). In 1989, Stratasys Inc. co-founded by Scott Crump filed for a patent for Fused Deposition Modelling which was issued in 1992 (3D printing, 2014). Stratasys alongside 3D systems was another corporate giant 
in the printing world. Crump discovered this invention while he was using hot glue gun to build layers of a toy frog for his daughter. By 1992, Stratasys introduced its first 3D printer "3D Modeler" (Barnett, 2014). Other 3D printing technologies and processes were also emerging during these years, namely Ballistic Particle Manufacturing originally patented by William Masters, Laminated Object Manufacturing originally patented by Michael Feygin, Solid Ground Curing originally patented by Itzchak Pomerantz et al., and "three dimensional printing" originally patented by Emanuel Sachs et al. And so the early 90s witnessed a growing number of competing companies in the rapid prototyping market but only three of the originals remain today-3D Systems, EOS and Stratasys.

Early 3D printing industry was dominated mostly by engineers who were the only people who used computer-aided design software to create 3D printed objects. The first two and a half decades of 3D printing was seen more like a specialized tool in a highly specialized profession (Emmino, 2012). It was not until the late 90s that scientist's started using 3D printing as a tool for organ development. In 2000, Object Geometries launched the first ever 3D inkjet printer followed by Zcorp introducing the first multicolor 3D printer. In 2001, Solidimension introduced the first desktop printer (Van Wijk \& Van Wijk, 2015). In 2002 scientists from the Wake Forest Institute for Regenerative Medicine were able to create a miniature functional kidney that was able to not only filter blood but produce urine as well in an animal (Van Wijk \& Van Wijk, 2015).

According to Heater (2014) though the first wave of 3D printers were developed by American entrepreneurs who were highly inventive in their garages, similar to Apple and HP, but the advent of modern desktop 3D printers surprisingly emerges from an open-source project that was launched by a British University. The mission of this project was simple, yet it seemed impossible and that was to create a machine that had the ability to replicate itself. Through a grant given to the University of Bath in the UK, Adrian Bowyer, a senior lecturer in mechanical engineering at that time, started working on a technology that would have the ability to replicate itself. On 2nd February 2004, RepRap (Replication Rapid-Prototyper Project) was invented with the goal to create a self-replicating device which could be used by individuals all over the world at low cost and the ability to manufacture objects that could be used in everyday life (all3dp, 2016). It could be said that RepRap was basically the start of a new open source movement that would allow individuals from all walks of life to use a technology that would enable them to create products on their own. Reprap was able to see the true colors of its success in the following year when the first replaceable part was printed by an early prototype. In 2008, the RepRap 1.0 Darwin successfully printed out half of its own rapid prototyped components (Heater, 2014).

2007 saw the open source movement of 3D printing when three individuals came together in a hackerspace tech community to create an open source company known as MakerBot. It was followed by the opening of an online repository known as Thingiverse that allowed individuals from all over the world to build a community where they could use 3D printing as a means to design and print. 2012 was the year that alternative 3D printing processes were introduced at the entry level of the market. It was also the year that many different mainstream media channels picked up on the technology. 2013 was a year of significant growth and consolidation. Various 3D applications are being developed in different sectors such as medicine, aerospace, automotive, jewelry, art, design, 
architecture, education, food, and many more (Barnett, 2014). 2015 was the year of major developments in the 3D printing sector such as medical advancement with regards to facial surgery; advances in metal 3D printing; 3D printed houses; Nike, Adidas and New creations creating 3D-printed shoes; the joining of major corporations such as Michelin, HP, Canon, Ricoh, Toshiba, Lenovo, Autodesk and Apple; and NASA launching 3D printers in space (Kira 2015).

However, there is still a gap between what 3D printing technology can do and what it will end up being used for and it has led to the development of many startups working in these different sectors. More and more startups and new ventures are coming into the $3 \mathrm{D}$ printing industry and trying to bring new applications which could lead to the possibility of evolution of this industry ${ }^{1}$

\section{Data collection}

Data collection was a three-part process based on (1) available documentation; (2) semi-structured, face-to-face interviews; and (3) observations. Our main source of information was collected through the interviews and the documentation and observations assisted us in triangulation of the data and to support any claims made by the participants, where deemed necessary (Miles \& Huberman, 1994).

\section{Documentation}

Data collection began by going through existing "internal" and "external" sources (Forbes \& Kirsch, 2011) such as documents, existing interviews, archival data, online articles, company websites, reports, books, and videos. It was necessary to gather as much information available to determine whether there were enough sources available. Most of the archival data was collected from the Wohler Associates webpage where the owner Terry Wohler had provided information regarding 3D printing from his own personal account. The archives dated from 2003 to 2017 and around 180 documents were collected for analysis. Through this, enough information was gathered that allowed one to understand and identify the key actors that were involved in the industry from the beginning. This process of instrumentation gave some direction and clarification regarding what kind of data was needed, from whom it can be extracted and what kind of analysis will be required in the research process (Miles, Huberman \& Saldaña 2014).

\section{Observations}

Field research was also part of the process (Forbes \& Kirsch, 2011) where 3D printing conferences and workshop such as the "Maker Faire" in Rome, Italy the "Inside3Dprinting" in New York and other local events organized by 3D printing startups were visited. The purpose was to get further information in terms of what special expressions were used (if any) by the people involved in the industry or if they had a specific language that they spoke among one another. Detailed notes were taken during the observation period, specifically, while meeting these individuals that assisted in recording their reactions and helped in forming the initial questions.

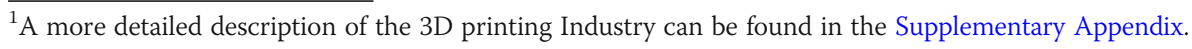




\section{Interviews}

The main source of data, however, was gathered through phenomenological semi-structured interviews from various actors belonging to the $3 \mathrm{D}$ printing industry. The objective was to understand the emergence of industries from an actor perspective which meant deriving theory from first person accounts (Gentles, Charles, Ploeg, and McKibbon 2015) while allowing the interviewer and/or the interviewee the flexibility to diverge their responses in more detail (Gill, Stewart, Treasure and Chadwick 2008). Such method generally leads to discovery of information that is important to participants but my not have been deemed pertinent by the researcher or research team. Through secondary research and observation, it was made sure that the interview questions were designed in such a way that they were clear and easy to understand to collect interpretable results (Patton, 2015). It was also made sure that interview questions were flexible enough to cater to the type of individual that was being interviewed. For example, questions such as, "When did you first hear about this technology?" "How did you get involved in this industry?" "Why is 3D printing term so dominant in your view?" This led to more probing questions and further gathering of information. Ethical issues were also part of the interviewing process where the participants were informed beforehand about the nature of the research and their permission was asked to record the interviews (Miles \& Huberman 2014).

\section{Sampling}

Chosen sampling for this study was small and purposive (Gartner \& Birley, 2002; Marshall, 1996; Miles \& Huberman 2014; Pratt, 2009) to "yield the most relevant and plentiful data" (Yin, 2011, pp. 88) as well as to "obtain the broadest range of information and perspectives" (Kuzel, 1992, pp. 37). Considering the pre-emergence phase of the industry and the actor perspective the sample of individuals was grounded on a certain criterion. This was based on how far back they went to the 3D printing technology as well as how well experienced they were in terms of their involvement with the industry. Based on the information collected from the secondary research, a database of the prominent individuals that were part of the industry was constructed. Out of those individuals, 2-3 main key players were shortlisted based on the degree of their experience, knowledge, and role. Furthermore, a detailed study was done on the participants that were attending the "Inside3Dprinting" conference in New York. This was done by going through their company profile and professional profile to determine whether they fit the criteria. Around 10 participants were shortlisted and were contacted through email prior to the event asking them for an interview. Some of the participants replied positively while few responded that they will not have enough time to give an interview. However, interviews with 4 participants were secured from the event. Further participants were gathered through different mediums such as direct emails, connecting through LinkedIn, Facebook groups, personal websites, and through referrals. In total, 15 participants were secured out of which 9 were male and 6 were female. Their profiles were a blend of different backgrounds that ranged from academics, engineers, journalist, designers, management orientated, and self-employed. The purpose of choosing such a sample was to be able to allow as much as diversity possible; however, this does not necessarily mean that they are the single representatives. 
The interview process was based on an unscripted framework where the context and the type of participant were kept in mind. Furthermore, the interviews were an informal mode of conversation that lead to deep discussions and probing questions hence leading to two-way interactions (Yin, 2011). Most of the interviews lasted between ranges of 30 to 60 to $90 \mathrm{~min}$. In total, the number of hours of the interview was around $583 \mathrm{~h}$. Those that were part of the technology since the beginning (that is the $80 \mathrm{~s}$ and 90s) took the longest duration since they were enthusiastic in providing more information. This required intense listening and to make sure that we heard and understood what they were trying to convey (Rubin \& Rubin, 1995) while simultaneously making mental and physical notes of further questions one can or may ask them. Some interviews were taken face to face, while some occurred through Skype and telephone. As participants were from the UK, the USA, and Europe, most mediums of interview took place through Skype/telephone. All interviews were recorded with the consent of the interviewees and they were transcribed respectively. Table 1 provides information of the participants.

\section{Data analysis}

The interviews were transcribed and then entered in NVivo (qualitative software) (Strauss \& Corbin, 1990). A quick analysis was done by reading through the interviews and developing various nodes (Bazeley \& Jackson, 2013). Specific quotes were then highlighted from the interviews and entered in the respective nodes that fit well with them. For a deeper and thorough analysis, each interview was read and prescribed through a line by line open coding method (Strauss \& Corbin, 1998) where efforts were made to derive concepts from the information that the interviewee had provided.

Table 1 Participant data

\begin{tabular}{|c|c|c|c|c|}
\hline Participant & Occupation & Gender & Background & Organization \\
\hline$\overline{A B}$ & Owner/inventor & M & $\begin{array}{l}\text { Engineer/academic } \\
\text { (retired) }\end{array}$ & RepRap \\
\hline $\mathrm{CO}$ & Additive manufacturing engineer & $\mathrm{F}$ & Engineer & LAl International \\
\hline $\mathrm{CL}$ & CMO/CEO (former) & $\mathrm{F}$ & $\begin{array}{l}\text { Marketing and sales } \\
\text { professional }\end{array}$ & $\begin{array}{l}\text { 3D Systems/Desktop } \\
\text { Factory }\end{array}$ \\
\hline $\mathrm{CP}$ & Self-employed/sculptor/product designer & M & Designer & Pardell \\
\hline DG & VP business development & M & Engineer & 3D Hubs \\
\hline DL & Chief investment officer & M & Investment advisor & 3D Tech Plus \\
\hline HC & CEONP & $\mathrm{F}$ & Engineer & Stratonics \\
\hline JM & 3D printing historian/physicist & M & Engineer & Layer Grown Model L.L.C \\
\hline MN & President & M & Management & Fabrisonic \\
\hline MV & Founder/CEO & M & Engineer & 3Degrees \\
\hline NT & Founder/general manager & $\mathrm{F}$ & Management & $\begin{array}{l}\text { Women in 3D Printing/ } \\
\text { Sculpteo }\end{array}$ \\
\hline RG & Creative director/experiential technologist & M & Designer & Son.Im \\
\hline SG & Editor in chief & $\mathrm{F}$ & Journalist & 3D Print.com \\
\hline SC & Owner/inventor & M & Engineer & Stratasys \\
\hline SH & Owner & $\mathrm{F}$ & Fashion designer & Heisel \\
\hline
\end{tabular}




\section{Findings}

After coding, similar concepts were then grouped into specific categories. Following the Gioia methodology, several first order codes were developed by reading the interviews. Then, second order themes from the codes were derived which then lead to the development of aggregate dimensions. This formed a data structure as shown in Fig. 1 (Gioia Corley and Hamilton 2013). The findings are discussed further.

\section{First order codes}

In the initial reading of the transcription, several first order (informant) terms were identified (Van Mannen 1979). These were followed with descriptive accounts as it allowed unpacking the content and nature of the theme. It led to detection of content, allowed refined categorization and assigning of the descriptive data to these categories followed by classification where groups of categories are given classes at a higher abstract level (Ritchie, Spencer and O'Conner 2003) that is leading to second order themes. Figure 1 shows the descriptive content in the first column labeled first order codes. For validity and reliability, the information that was being provided by the

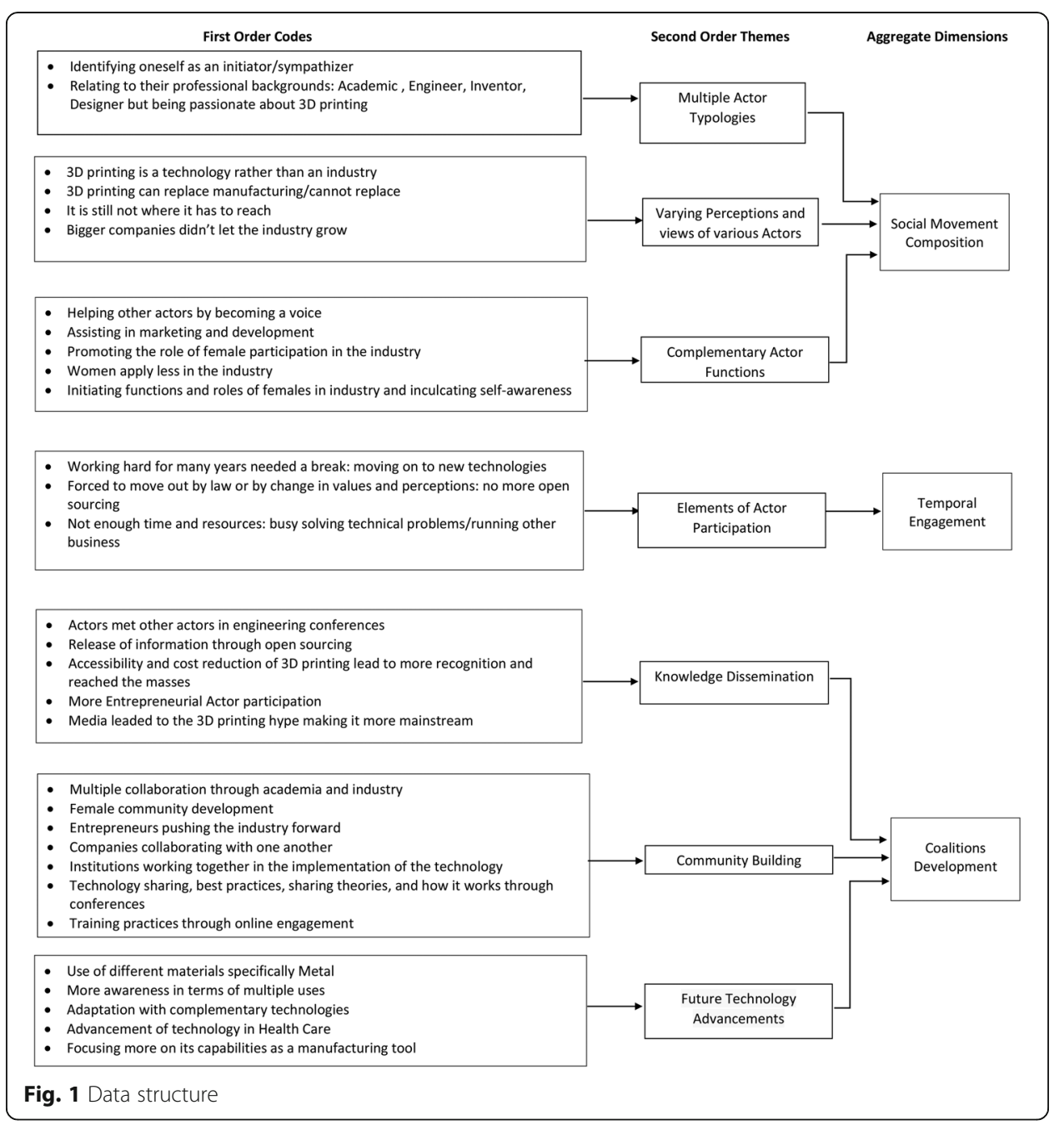


respondents was triangulated (Baxter \& Jack, 2008; Golafshani, 2003; Patton, 2015). For example, when one participant was asked when he/she heard about the technology, the participant mentioned that he/she read it in a magazine published in 1974. The source of the magazine was cross checked. This was done consistently wherever there was a need. Once the categories were classified, it went on with the second order themes.

\section{Second order themes}

The identified themes were given specific labels as seen in the second column of Fig. 1. According to Gioia, Corley, and Hamilton (2013) these emerging themes may help in describing and explaining the phenomena being observed. More importantly it provides space to focus and examine the emergence of new themes: assuming entrepreneurial agency (Goss \& Sadler-Smith, 2018), exploring different actor typologies, their perceptions, functions, and types of involvement.

\section{Actor typologies}

Actor typologies help to understand who has been playing fundamental roles in achieving collective goals (McCarth and Zald 1987). Most of the participants were engineers, who were also inventors of the technology itself, while some were those that had non-scientific backgrounds such as designers, academics, researchers, and managers. Engineers had an obvious interest in the technology because of their background but it was interesting to find other actors of different backgrounds interested in the technology as well. In SM, diverse group of actors connect with one another since they are working towards similar goals but why the $3 \mathrm{D}$ printing actors connected with one another having diverse backgrounds? The participants were asked when it was the first time they heard about this technology? This allowed a deeper insight into how they became involved with this technology. Most of the respondents got to know about the technology through different mediums such as magazines, videos, YouTube, word of mouth, through academia, jewelry exhibitions, and maker

faire's. Some, however, got into it by accident when they were looking for a job or while they were already working in a company that introduced them to the technology:

Well 3D printing the first time I heard about it was in like 89 or 91 when I saw some demonstration of the potential for the technology. But you know it was pretty coarse and it was ridiculously expensive.-CP

Most of the actors did not come into the industry with a pure entrepreneurial objective. They were mostly involved in it either as researchers, inventors, hobbyists, designers or engineers whom out of some later integrated the technology as part of their companies or started their own entrepreneurial initiative(s):

I am more of an academic than an entrepreneur really. I am not sure I am a very good business person. I'm pleased to say our company makes profits but I wouldn't really think of myself as being an entrepreneur. $-A B$

The participants showed similar behavior in the way they identified themselves to the industry or the technology itself. This also correlated with the initial observation which 
was made during the data collection phase when various 3D printing individuals were visited at the maker faire in Rome. This was observed while asking them to introduce themselves or through asking questions. Some were quick in identifying themselves as initiators/ protagonists while some were humbler about it. For most of them, it gave a sense of recognition and a sense of being an influential part of the industry. What can be deduced from these findings is that though these participants had different backgrounds they had one thing in common and that was "3D printing" and their objective to be a part of this industry and to see it progress further, something that is similar in a SM setting as participants within a movement are working towards the same goals.

\section{Views/perception}

The actors' perceptions and, thus, how they see the environment are instrumental for the potential development of a movement identity (Eyerman \& Jamison, 1991). Therefore, we explore the actor's perspectives. Though the participants were diverse, they shared a similar interest in 3D printing. However, there were also some varying views and perceptions of the participants specifically regarding the application of the 3D printing technology in terms of it replacing manufacturing. Most respondents believed that while $3 \mathrm{D}$ printing was initially thought to replace manufacturing, realistically it is not possible:

I never believed it would replace manufacturing, in certain industries it won't touch manufacturing. My father was a tool and dyeing engineer and they would spit out a hundred thousand products in a minute...just boom boom...3D printing will never replace that-DL

3D printing could act as a technology that aids manufacturing, but it cannot replace manufacturing completely. However, other respondents were more optimistic and believed that $3 \mathrm{D}$ printing would outnumber traditional manufacturing to a certain extent:

So, we will have machines who can take printing electronic chips as oppose to the conventional process for making electronic chips which will eventually end. Umm and we will have machines building large engineering structures, umm components for large engineering structures at least. $-\mathrm{AB}$

Almost all the participants believed that 3D printing was an industry except one who claimed that he/she viewed 3D printing as a technology that assists other industries:

I would comment that I don't look at 3D printing as an industry. I look at it as a set a set of technologies-CL

Despite having different views and perception, all the actors were still involved in the industry and shared similar interests to a great extent. This highlights another important component that is parallel with SM theory where participants despite having different views come together because they share similar goals. 
All 15 participants agreed that 3D printing was an industry (technology) that had tremendous growth opportunities. They believed that the industry could grow further by acting as a complementary technology in industries such as aerospace and healthcare and that entrepreneurs will push the industry forward:

I think a lot of the complementary technologies will continue to evolve and push the boundaries of it and the entrepreneurs of the world will continue to push the boundaries and how we're going to use it. So definitely.-CO.

\section{Actor functions}

Actors need to mobilize resources for collective actions and the functions of actors that participate in promoting an industry needs to be investigated (McCarthy and Zald 1987). Davis and Thompson (1994) state that actors portray their shared interests into a collective action. Group formations around interests of a set of actors are governed by certain feature that define the interests, i.e., small in number, shared, and/or readily recognized. While interviewing the participants, a certain pattern was noticed where the actors were sort of performing complementary functions. In simpler words, one or more actors were assisting one or more other actors either through becoming their voice or by creating a certain platform that allowed other actors to come together:

So instead of letting the then CEO and the founder hide behind the curtain back in headquarters. I made him get out and talk about what they were doing, and I got them on to the podium and I got him to speak and that was not easy because these guys were more technologist than and they were speakers. Scott Crump is just like that. He's very intelligent and insightful but he's not a great speaker. So, you had to really work with them, but I think ultimately we, you know the reason I joined was to help get that message out and go get new users and to create case studies and that was a tough part-CL

This showed that some actors had a more complementary role in which they tried to push other actors forward. By doing so these helped the actors to reach out other actors and hence create more knowledge and awareness about 3D printing. Furthermore, one participant recognized that there was a certain gender gap within the industry and a lot of actors specifically female actors were missing from the industry. Hence, she started to build an all women 3D printing platform called "Women in 3D printing" that not only encouraged female participants but also pushed other organizations and actors belonging to the $3 \mathrm{D}$ printing industry to become a part of this community. It kind of formed a movement organization that created awareness of the existence of female participants and initiated functions and roles of females in the industry:

Yeah I have to say NT has done a fabulous job. I mean it wasn't that long ago I met her at a conference and she is like I am starting to put this little group together and I am like okay and now I see all that she is doing and wow and so she has told you know if you need a resource right, of women in Additive and boy she has got a primo list- $\mathrm{HC}$ 
This also highlights a SM pattern where actors are coming together and forming collations by meeting in conferences and meetups and hence forming a movement type pattern.

\section{Elements of actor participation}

Participation is an important element in SM since without participants a movement cannot thrive (Weber \& King, 2014). However, participation might be only temporal and drop-outs might happen (McCarthy and Zald, 1987). Most of the actors that were interviewed had been in the industry for long but what was also observed was that some of them had a more temporal relationship with the industry. By temporal it is meant that though the participants were involved in the industry, at some moment in time, they had decided to either leave the industry completely or partially. There were several reasons that came up as to why the actors made such a decision. These were divided under the labels of voluntary drop-out and involuntary drop-out. Within SM settings, there is an assumption that every individual that participates has a certain threshold value that determines how many other participants must be there before that individual decides to participate (Granovetter, 1978; Granovetter \& Song, 1983, 1986). However, Sandell (1999) tries to extend this knowledge by examining interpersonal influences that leads to drop-out behavior by participants. In other words, even in SMs, there exist temporal behaviors from participants which means that participants may drop-out from the movement at any given time. The reasons in SM theory regarding drop-out varies; however, in this study, the focus will be on the reasons that were discovered while interviewing the participants. Firstly, under voluntary drop-out, there were reasons such as moving on and finding other opportunities, problem of availability, less resources, and time. However, age may have played a role as well:

Now I happen to be an older individual, so I'm 66, so whatever my next decision is and I will probably make something in the next 3 to 4 months, it's going to be more about helping people understand the value of the Technologies or helping people achieve their greatest potential because I've had an amazing career and that might be more meaningful than just focusing on a single technology $-\mathrm{CL}$

Involuntary drop-outs occurred when actors were forced by law or by change in perceptions and values. One respondent gave a detailed account of forced drop-out. For example, the founder of the Model Maker, Roy Sanders was legally sued by Solidscape (3D printing company) based on patent infringement ${ }^{2}$. Another involuntary drop-out that was discovered was the difference of opinion that had formed between two founders, Bre Pettis and Zach Hoeken, who had started the company MakerBot. The company originated on the principal value of keeping it open source; however, Bre Pettis decided it was time to make the company close sourced which went against the values of Zach Hoeken who believed in keeping it open sourced. Hence, Zach Hoeken eventually had to drop-out of the company forcefully:

${ }^{2}$ https://www.solidscape.com/news/solidscape-sues-sanders-design-international-its-founder-royden-sandersand-its-president-albin-hastbacka/16 
In 2009, I invited my friends Adam Mayer and Bre Pettis to go into business with me building 3D printers. Thus, MakerBot Industries was born. Fast forward to April 2012 when I was forced out of the very same company. I do not support any move that restricts the open nature of the MakerBot hardware, electronics, software, firmware, or other open projects. MakerBot was built on a foundation of open hardware projects such as RepRap and Arduino, as well as using many open software projects for development of our own software. I remain a staunch supporter of the open source movement, and I believe the ideals and goals of Open Source Hardware remain true. I have never wavered from this stance, and I hope that I never do. Future me, beware. (Hoeken, 2012)

The drop-out did, however, not only concern just a single firm or an individual but a whole subgroup within the 3DP movement. For many, the 3DP technology was next open technology, so many technology interested individuals had chosen 3DP over other technology because it was going to be open. Makerbot's move was a strong signal that the future would be different and many disappointed dropped out. What was observed from the responses and behavior of these actors was that participation in the emergence of an industry can be on a temporary basis. The choice of leaving an industry may be dependent on many factors such as personal motivations, differences in opinions and/or forced drop-out.

\section{Knowledge dissemination}

Knowledge sharing and dissemination are critical to create opportunities for effective collective action (Tarrow, 1998). The 3D printing industry was a very quiet affair from the start and it only started gaining recognition as an industry when it started coming into the limelight:

3D printing was held back for a long time because it was so tightly controlled by a few companies and their patents.- $\mathrm{SH}$.

During the data collection period, it was understood that the open source movement had a significant role in the 3D printing industry that allowed the technology to be more accessible. However, open sourcing of the technology only started in 2005 when RepRap was developed. It was important to identify how diffusion of knowledge took place which allowed the industry to gain traction. The senior participants mentioned that they were unaware of the existence of other companies because they were all specializing in one specific form of 3D printing technology. It was only during conferences that they were able to gain knowledge of the existence of other companies that were working on $3 \mathrm{D}$ printing as well. Here, it is important to mention that through secondary data collection important archival information was collected from the personal blog of Terry Wohler of Wohler Associates. Although the first conferences about 3D printing were organized, they remained largely unknown to the general public and frequented only by technology users. This highlights the fact that 3D printing at that time was not considered a separate industry and was mentioned more as a technology, used by different industries, in engineering conferences: 
I attended COFES2003 last week in Scottsdale, Arizona. (COFES is The Congress of the Future of Engineering Software.) I sat in on an architectural/engineering/ construction industry session that debated the pros and cons of designing and communicating in $2 \mathrm{D}$ versus $3 \mathrm{D}$. It became clear that the $\mathrm{A} / \mathrm{E} / \mathrm{C}$ industry has not progressed much in its transition from $2 \mathrm{D}$ to $3 \mathrm{D}$ over the past several years, compared to manufacturing (Wohlers 2003).

Though conferences related to 3D printing started emerging, they were still accessible and known to only a few actors that were using the technology. Here, is where open source played its part in spreading the knowledge to the masses. As mentioned before open source was an important element in making 3D printing accessible and most of the credit goes to the academic researcher who developed RepRap, a self-replicating machine:

When I started the RepRap project, I decided to make it open source and give all the software, all the 3D cat designs everything you needed to make a machine all the documentation. I decided to give that all away for no cost and no royalties. $-\mathrm{AB}$

By making it open source, 3D printing technology became less costly and more accessible:

Yeah I think the open source piece was very critical to the success. It's really tough to say what would have happened without it but I mean the industry basically sat idle for so long and then the open-source aspect help kick-start it and bring it to the limelight and most average users they maybe don't even realize that it the technology 3D printing has been out there for such a while.-DG

Though most participants agreed that open source was essential for making 3D printing more prominent, they also mentioned how it got overhyped which made the industry lose its focus:

The hype was ultimately quite damaging because the technology presented at the time couldn't live up to what people were saying and increasingly now more premises are being met much more is possible but people don't take it seriously because they don't see a purpose before and the technology just wasn't there yet and it's still not there yet to a great extent.-SG

The respondent believed that the hype was fueled mostly by media outlets, presidential speeches, movies, articles, etc. which although brought positivity to the industry but there were also some negative impacts as well. However, they also mentioned how they were happy that the hype cycle had died now which meant the 3D printing could be more focused now:

I'm actually quite happy that the hype has died down. I think it will be a lot easier as there aren't any expectations. But long term there is the growth of industry 
there. There are a lot of incredible things that you can do, that you can't do any other way. $-\mathrm{MV}$

It is worth mentioning that one of the positive effects of the open sourcing and hype was the entry of entrepreneurial actors. Once RepRap came into the market entrepreneurs like Bre Pettis and Zach Hoeken started working on the technology. Individuals with entrepreneurial initiatives started meeting in places such as hackerspaces and Fablabs to use the technology and start their own startups.

The participants were further asked about what their views were on the entrepreneurs, who on the onset of the hype started opening their own 3D printing startups. Most of them believed that entrepreneurs were a driving factor that had pushed the industry forward:

I think that the entrepreneurial role in additive is probably similar to that of a lot of other technologies in that they are going to be the ones that are going to push the limits and they're going to be the ones that are going to drive the creativity. So, I think that it's very similar you know it's going to continue to be pushed outside the box and see what we can see what we can do with the technology. I think that those startup have most entrepreneurial like ideas have already really influenced a lot of the new things that we can do and when you pair the entrepreneurial spirit with the background and the funding and the research that these big organizations want to do that's where you're actually going to get substantial progress.-CO.

What can be deduced from the responses is that entrepreneurs play a vital role in bringing the industry forward but also through the collective efforts with other actors, organizations, etc. However, a few stated that the though entrepreneurs did push the industry forward being less knowledgeable caused more problems:

A lot of the entrepreneurs coming into it really don't know much about the history nor much about the technology. They were actually seen as causes of some problems, because it started giving the industry bad name because they come in with poor quality and poor engineering. That's not to say that's true to a point because there are some very good innovators out there, but I think 7 out of 10 entering it are causing more problems in the industry rather than solving problems. $-\mathrm{MV}$

The outcome from these responses demonstrated that entrepreneurs were indeed involved in bringing the industry forward, but it also meant that they needed to be equipped with certain knowledge and resources that made them capable enough to create more innovative products and services with the technology.

\section{Community building}

Community building is an essential precondition for promoting effective collective action (Welter, 2011; Weber \& King, 2014). While the open source led to more dissemination of knowledge, it meant more doors opened for more collaborations and engagements between different actors and organizations such as academia, which also fostered community building: 
I know that if we had gone alone and no one else was there for let's say 20 years...I don't think we would had grown anywhere near as fast because we were getting people to invest in new idea, new technologies, new markets, new customers that didn't exist, new profits that never existed.-SC

Some participants mentioned the importance of collaborations and community building within schools and universities while some emphasized how the 3D printing was an ecosystem that was helping in development and sharing of strategies and practices. They unanimously agreed that 3D printing industry was very collaborative, and this led to sharing of resources such as funds and knowledge enabling the growth of the industry.

A very interesting outlook was from the female perspective. As mentioned in the previous theme, actors played complementary roles and in 3D printing industry a prominent example is the organization called "Women in 3D printing." The person behind the organization believed that it was essential to bring forward the women in 3D printing to bring more diversity in the industry:

I really truly think that the next big change in the $3 \mathrm{~d}$ printing comes from different backgrounds and we have to share this. And this is really how the idea of the blog started. The idea was to share the background of the women in the 3D industry.-NT

\section{Aggregate dimensions}

From these themes three aggregate dimensions, "Social Movement Composition," "Temporal Engagement," and "Coalition Development" were identified (see column 3 of Fig. 1). The first three themes showed a diverse set of actors pursing similar goals for 3D printing coming together and acting as complementors hence creating a SM composition. The fourth theme highlights the participants' motivation to be part of an industry, hence creating temporal engagement. The last three reveal further strengthening of ties and networks between actors, communities, and organizations that led towards development of coalitions. This formed the complete data structure as shown in Fig. 1, which is an important component that demonstrates the detailed and rigorous analytical phase of qualitative research.

\section{Discussion}

The purpose of this study was to better understand the emergence of an industry, in this case the 3D printing industry, with the focus on the pre-emergence phase. Our analysis of the pre-emergence phase of the 3D printing industry suggests that process of industry emergence goes through three initial phases: social movement composition, temporal engagement, and industry foundation; they form our aggregate dimensions. All three phases can be related to the idea of redundancy. In the following section, we will discuss how our findings contribute to the industry emergence literature and generate propositions.

\section{Diversity and movement formation}

First, we derived social movement composition based on the actor typologies, views, and the roles they played which, displayed the actors as part of a social process, like SMs, 
where they all had mutual interests and despite having different views were willing to engage with one another. While these findings explain the components of the SM process, what is not apparent is how this movement actually takes off? To understand this, we need to explore the reasons behind how the movement is formed with these diverse actors. Actors' primary goals play a relevant role. We could speak of the specific objective of the participants and the meta-objective that forms the SM. Entrepreneurs are interested in creating their firms and industries (Swaminathan and Wade, 2001), some stakeholders in the entrepreneurial ecosystems favor startups to create industries (Stam \& Spigel 2017). However, other actors might have other primary goals, i.e., an engineer in materials to adapt 3DP to different materials for the sake of scientific knowledge. Thus, actors are willing to participate in a given movement if the movement is functional to their primary goals. To fit the primary goals, there needs to be a meta-goal (or even more meta-goals) that is large enough to gather diverse groups of people (Klandermans and Oegema 1987). An important group of supporters at the beginning were individuals interested in open source and they saw 3D printing as the next open technology. Their primary goal was open technology. Women in tech jumped also on 3D printing because they saw it as an opportunity to increase the weight of woman in technology in general, forming user communities (De Jong \& De Bruijn, 2013). Others used 3D printing as a means for challenging the law, especially those on strict IP appropriability. The famous case of the non-profit organization "Defense Distributed" that tried to diffuse blueprints of fully 3D printable guns challenged the state (Barnett, 2014). Obviously, there were a core group of initial actors which primary interest was the specific technology. They started to engage with others who had similar goals and hence a movement started forming (Earl, 2017). However, different actors with different primary goals form the movement and therefore sustain the initial core group, hence, forming a collective good (Klandermans and Oegema 1987). Even, if primary goals might differ, all saw enough potential in 3D printing to serve as a vehicle for the goals, so that the development of 3DP was a sufficient metagoal to accommodate for a variety of interests. Hence, this leads to the following proposition:

Proposition 1: The probability of industry emergence increases with its inherent meta-objective that allows to align the primary goals of a variety of subgroups and actors and therefore to increase the number of participants of the movement.

Proposition 1 would also indicate that very narrow technologies with a limited set of applications would be less likely to emerge as a new industry even if there might be a more solid core group of technology specialists, as they create insufficient levels of redundancy.

\section{Meta-objectives within movement participation}

Second, and following our first proposition, temporal engagement has a key role for understanding industry emergence. So, if meta-goals help to gather more groups with varying primary interests, industry emergence depends on the number of actors joining the movement and if they stay effectively long enough with the movement. On the other hand, the same goal may fade away when faced with adverse circumstances. The two questions depend on other alternatives to serve primary goals of subgroups and the persistence of the meta-goals. Our findings show that actors during the emergence 
process faced voluntary and/or involuntary drop-outs. Movements are in competition for resources such as governmental funds for research and interests of investors. To have a relevant impact, movement size is critical (Johnson, 2008): it concerns both the attraction and retention of actors for a useful time span. If there are less actors participating, then the movement may be too small to enable industry emergence. In the case of the 3D printing industry, the actor participation was diversified, and the number of participants grew with time which led to the growth of the movement. MakerBot is an emblematic case when one of the co-founders decided to switch from an open-source approach to a proprietary system (Barnett, 2014). Not only did other co-founders leave the firm but also all those actors who believed in open source began to leave the movement (Brown, 2012) putting a real threat to industry emergence. So basically, just as movement size is decisive for the growth of any SM (Van Dyke and Amos 2017), it is also decisive for industry emergence; however, that also means that it is not the absolute number of people dedicated to a given industry or technology but the total number of people that can somehow ascribe to the meta-goals of an industry. Ironically, industry emergence is more likely, the more the people join the movement that are not necessarily interested in the emergence of a specific industry and that these people stay long enough within the movement. Therefore, the open source community, women in tech community, etc. are critical in pre-emergence phases.

We may see temporal engagement as a "bandwagon effect" or "domino" effect, i.e., being part of a movement due to social influences. According to Granovetter (1978), different individuals have different levels of thresholds which explain why collective action can happen despite general unfavorable preferences and how it causes a bandwagon effect. For example, some individuals may have higher thresholds while some may have lower thresholds. Those with higher thresholds may be seen as protagonists /leaders that have highly specific goals while those with lower thresholds may be seen as sympathizers/bystanders with less specific but coherent goals. Within the movement, the higher threshold actors will attract other actors that may have lower thresholds which creates a bandwagon effect. This also means that concentrically over time, people might join the movement despite having less interest in the specific initial goal. For instance, after the entry of woman in tech, actually gay groups became interested in the use of 3DP technology, such as the gay group on the Thingiverse 3D printing forum. This leads to our second proposition.

Proposition 2: Industry emergence is dependent on the relative degree of actor diversification and participation attracted by the movements' meta-objectives. The more diversified and the greater participation of actors, the higher the initial growth of the movement. The size will attract necessary resources to realize the specific goals; thus, the length and timing of temporal engagement of subgroups of a movement determine the likelihood of emergence of industries.

From proposition 2 derives an important insight also for entrepreneurial ecosystems. Entrepreneurial ecosystems need to attract and mobilize public and private resources for their development (Spigel and Harrison 2018). Assuming limited resources, alternative allocation opportunities for these resources and therefore competition, movement size will influence the probability of the development of entrepreneurial ecosystems. 


\section{Availability hypothesis and degree of participation}

Our findings suggest that collective action was a process that first started from actors connecting with one another. This led to spreading of knowledge and awareness which also led towards more research into the technology. Subsequently, subgroups also started joining the collective action because of alignment with meta-objective. The information spread to the masses once open source was implemented on 3D printing technology (For example, The MakerBot). It became more accessible and less costly thereby creating a hype that brought in a flux of different actors, institutions, organizations, communities, etc. This provided opportunities for entrepreneurs who were interested in the technology and had innovative ideas to launch new products and services. Some early entrepreneurs may be identified as user entrepreneurs who were familiar with the technology and through a collective process were able to bring forward an innovative product/service (Shah \& Tripsas, 2007).

However, if temporal engagement of actors is a function of the primary interest and meta-goals of a movement, it is important to understand what other factors make actors stay in a movement to allow industry emergence. As already discussed, it is the question of primary goals and alternative options. SM theory offers also another explanation in the so-called availability hypothesis. The availability hypothesis states that the degree of participation in a movement is dependent on the requirements of the movement in terms of resources including time and the availability of actors to dedicate these resources to the movement (McAdam, 1986). In the case of industry emergence, there might be moment of infrequent and less regular collective action, which allows more people to participate (in SM, we could think of occasional protest walks); however, with increasing resource mobilization (Jenkins 1983), the collective action becomes more continuous (e.g., continuous protest marches), requiring more and more dedication of resources (e.g., one-month occupation of a house). As a consequence, those loosely coupled groups need to evaluate the value of participation against the cost, or simply they will not be able to always be available. A professor at the university might be able to present at a few events to give support but not present continuously on a technology roadshow.

The concept of opportunity costs within entrepreneurship states that entrepreneurs are likely to take over entrepreneurial activates when the opportunity costs are lower than the value of the opportunity itself (Amit, Muller and Cockburn 1995). The same argument was also made for user entrepreneurship (Shah \& Tripsas, 2007), especially for products related to babies and toddlers that were often created by parent user entrepreneurs during their parenting time. However, availability hypothesis (McAdam, 1986) extends this concept by making it more general. In the mentioned case, these parents were available for a given time but also constrained in their total ability. In case of industry emergence, actors having a lower opportunity cost will stick to the movement generally longer than those actors that have higher opportunity costs. Therefore, it is more likely that people with high opportunity costs need to exhibit at the same time high risk-taking propensity in order to continue substantial support. We could think of a researcher that calls in sick at work to make him or her-self available to a movement (the researcher would have high opportunity costs but take risks). This in turn would also means that the probability is generally high that movements' protagonists are made of a high proportion of outsiders. Outsiders are often considered a 
source of radical innovation (Ferriani, Garnsey and Probert 2008) and their lack of constraints (work, family, reputation) makes them highly available to demanding movements.

This leads to the following proposition:

Proposition 3: Industry emergence is dependent on actors' availability or willingness to take risks, thereby growing the movement followed by their commitment through the subsequent stages.

\section{Conditions for industry emergence}

To summarize, the identification of the aggregate dimension leads to the development of an industry emergence process model as shown in Fig. 2. A dynamic relationship between the aggregate dimensions that were established in column 3 of Fig. 1 is represented in the model. All three are important elements in the process of industry emergence. These three influences act on different levels and phases within the preemergence phase. The participation of highly diverse actors is related to the movements size; the question of how long participants stay with the movement is related to the successful shift in resource allocation and the number of sufficient available actors on the final emergence of the industry through people that are dedicated to the specific case of firm foundation and favoring industry emergence. So redundancy, an oversupply of participants, plays a role in industry emergence. This leads to the following proposition:

Proposition 4: The existence of meta-goals of a movement (influencing the movements size), the sufficient temporal engagement (assuring the attraction of necessary resources), and a sufficient number of available actors (for the realization of the specific objectives) are necessary conditions for industry emergence.

In proposition 4, we argue that a way larger and diverse community of available actors with non-permanent engagement finally create the favorable circumstances that allow a much smaller initial set of entrepreneurs to emerge and create new firms that will set the stage for further industry emergence and evolution.

\section{Contributions and limitations}

The contributions of this study show an effort to understand industry emergence from the pre-emergence phase through an actor perspective with the aid of SMs. The implications that can be derived from this study are not only limited to understanding industry emergence but also shifts the focus from the individual entrepreneurial hero to the community, or to the efforts of many other individuals (Garud \& Karnøe, 2003).

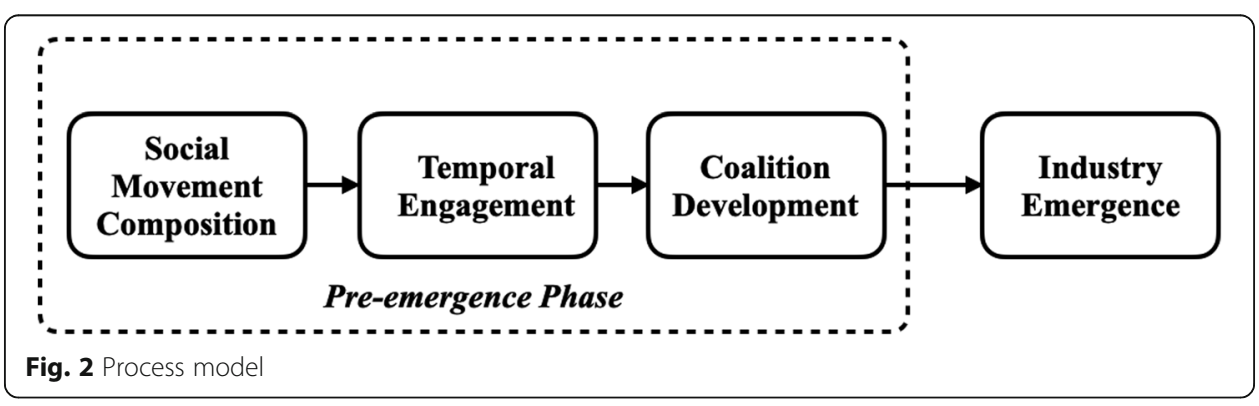


This study explains that industry emergence is a social process that does not emerge overnight, and social aspects are determinant in the growth of the industry where the concept of collective action cannot be disregarded. The notion that industries are created by entrepreneurs only explains half of the story which is more like the second half of the movie after the intermission. Scholars such as (Sine \& Lee, 2009; Schoonhoven \& Romanelli, 2001) themselves place importance on the amalgamation of collective action within the study of entrepreneurship. This study recognizes that collectivity between different actors is an integral part of the emergence process. Furthermore, it emphasizes that diversification of actors, coupled with their meta-objectives, and their availability of taking risks are essential factors that not only keep the movement alive but also pushes the industry forward. So, basically the movement builds a community that affects how resources are mobilized and how entrepreneurial opportunities start to emerge thereby allowing user entrepreneurs to create new and innovative firms leading towards a new industry. We have also tried to give an overview of how SM effects evolve as the industry grows (Carlos et al., 2014), but since the 3DPI is still emerging, it should be acknowledged that this is not definitive and the effects will change with the growth of the industry.

\section{Theoretical implications}

From a theoretical perspective, the implication of this study shows how SMs can be used as a tool to understand the process of industry emergence. It highlights the use of interdisciplinary research arenas within entrepreneurial studies that enables theorizing at a deeper level. Furthermore, it identifies the importance of actor centric studies that can help in understanding complex phenomenon such as industry emergence as well as how entrepreneurship theories can further develop. Furthermore, by using qualitative methods we were better able to understand the complexity of the emergence process which is somehow unexplained in the literature regarding industry emergence and entrepreneurship. It was critical to focus on actors for understanding what role they play and how they impact the industry emergence process and also to determine where, when, and how exactly entrepreneurial actors bring the industry forward. By doing so, we provide greater depth and understanding of the industry emergence process from an actor and entrepreneurial perspective.

There are two main contributions to theory. First, industry emergence literature is also somewhat goal centric. As it focuses on technology-driven entrepreneurs, the use of the technology is one of the primary goals for setting up the firms. We show that the technology might be a vehicle for a variety of primary goals that do not necessarily need the specific technology to reach the primary goal nor lead to new venture creation. Second, we extend the concept of opportunity to cost under the more general concept of availability (McAdam, 1986), which might also better explain why people with similar opportunity costs (but differing risk propensity) might make themselves available. It can also explain why people with differing opportunity levels and especially people with higher opportunity costs might initially engage in entrepreneurship (because they are more available).

\section{Managerial implications}

For policymakers, the research gives a direction that can enhance economic development initiatives. They can learn to make new strategies applicable in the creation of new industries. They need to understand that not one strategy can fit when it comes to 
understanding industry emergence. Specifically, with the advent of digital transformations and movement towards sustainability and circularity, there is an utmost need for policymakers to devise new strategies and to understand the social processes involved.

\section{Limitations}

This study has its own set of limitations. First, our study was limited to a single, embedded case study where we chose the 3D printing industry. While this approach gives an indepth inside, it reduces the generalizability and conclusions can only be drawn from the case to the theory (Yin, 2003). Considering that we wanted to understand the preemergence phase of an industry, the 3D printing industry provided us with a unique setting, as it is still in its emergence phase. Through this case we were able to draw conclusion from the rich data that we gathered thereby leading to theoretical propositions (Yin, 2011). We were able to interview a diverse set of actors that allowed us to gather contrasting views and a sufficient representation of the industry. It is possible that the conditions that we have identified for the emergence of 3D printing industry are not generalizable to other industries. However, we think that SM emergence is an important factor that may play an important role in industry emergence and may be applicable over other industries as it emphasizes on coalition effects. Future research on multiple industries can provide a more holistic view and contribute towards a richer understanding of the industry emergence process. Given that this is the first step towards understanding industry emergence from a SM and actor perspective it was incumbent to have an in-depth case study to form the basis of a clear and rich context and we also think that it can lead towards future research in the form of multiple case studies and empirical studies.

\section{Future research and conclusion}

There is a dearth in studies related to emerging industries, specifically in entrepreneurship studies, theoretically as well as empirically (Forbes \& Kirsch, 2011). Therefore, there is a need to address this gap and to produce more robust studies that can explain the phenomenon of industry emergence, specifically from the pre-emergence phase (Kirsch, Mooeen and Wadhwani 2014). Hence, in terms of future direction, this study can be implemented in different settings to get more alternative views and results regarding how SMs can assist in the creation of industries. Therefore, a multiple case study would be one way to examine more in detail the process and whether the effects are the same. Furthermore, due to digital innovation entrepreneurial ecosystems are also changing (Sussan and Acs 2017), which is affecting existing industries (e.g., construction, transportation) that are either being transformed into new industries or creating sub-industries. Therefore, applying a social movement approach to analyze how these new industries are being created is another research avenue. A rise of movements for a circular and sustainability economy is pushing industries, organizations, firms, and entrepreneurs to re-examine their business models (Oghazi \& Mostaghel, 2018). As these movements not only try to shift the allocation of to a new activity but actually try to transform the economic system, social movement theory might be an appropriate lens for studying this phenomenon. Furthermore, efforts should be made to collect empirical data relative to the 3D printing industry to gain more robust results leading to more theoretical as well as empirical studies. 
To conclude, the actor-based approach tries to lay a skeletal image of the process of industry emergence through a SM pattern. The objective is to shift the emphasis away from the entrepreneurial hero towards acknowledging that a socio-relational framework can be adopted in entrepreneurship studies. This study is a first step in this direction and could lead to further contributions to the entrepreneurship literature: not only for understanding industry emergence but also to make entrepreneurs, startups, firms, organizations, and policymakers aware of the embeddedness of their actions in a wider system in order to generate necessary collective action.

\section{Supplementary information}

Supplementary information accompanies this paper at https://doi.org/10.1186/s13731-020-00124-6.

Additional file 1. Supplementary Appendix. The History of the 3D Printing Industry.

\section{Abbreviations}

3D: Three dimensional; 3DPI: Three-dimensional printing industry; SM: Social movement

\section{Acknowledgements}

The authors would like to thank the Editor and two anonymous reviewers for their constructive comments on this manuscript.

\section{Authors' contributions}

The authors were jointly involved in all phases of the research. The authors contributed equally to this manuscript. The authors read and approved the final manuscript.

\section{Funding}

This work was supported by the Open Access Publishing Fund of the Free University of Bozen-Bolzano.

\section{Availability of data and materials}

The datasets generated and analyzed during the current study are not publicly available due to granted anonymity to the interviewees as typical in case study research but are available from the corresponding author on reasonable request.

\section{Competing interests}

The authors declare that they have no competing interests.

Received: 4 March 2020 Accepted: 30 June 2020

Published online: 28 September 2020

\section{References}

3D Printing. (2014). The free beginners guide to 3D printing. http://www.3dprintingindustry.com. Accessed 29 May 2016.

Agee, J. (2009). Developing qualitative research questions: A reflective process. International Journal of Qualitative Studies in Education, 22(4), 431-447.

Aldrich, H., \& Fiol, C. (1994). Fools rush in? The institutional context of industry creation. Entrepreneurship: Concepts, Theory and Perspective, 19(4), 105-127.

ALL3DP. (2016). The official history of the RepRap project. https://all3dp.com/history-of-the-reprap-project/. Accessed 29 May 2016

Amit, R., Muller, E. \& Cockburn, I. (1995). Opportunity costs and entrepreneurial activity. Journal of business venturing, 10(2),95-106.

Barnett, C. (2014). 3D printing: The next industrial revolution. Explaing the Future.com

Barnett, L. (2006). Waves of collectivizing: A dynamic model of competition and cooperation over the life of an industry. Corporate Reputation Review, 8(4), 272-292.

Baxter, P., \& Jack, S. (2008). Qualitative case study methodology: Study design and implementation for novice researchers. The Qualitative Report, 13(4), 544-559.

Bazeley, P., \& Jackson, K. (2013). Qualitative data analysis with NVivo (2nd ed.). London: Sage.

Bourell, D., Beaman, J., Leu, M., \& Rosen, D. (2009). A brief history of additive manufacturing and the 2009 roadmap for additive manufacturing: Looking back and looking ahead. US-Turkey Workshop on Rapid Technologies, 2, $2005-2005$.

Brown, R. (2012). Pulling back from open source hardware, MakerBot angers some adherents. https://www.cnet.com/news/ pulling-back-from-open-source-hardware-makerbot-angers-some-adherents/. Accessed 2 June 2016.

Carlos, C., Sine, W. D., Lee, B. H., \& Haveman, H. (2014). Gone with the wind: Industry development and the evolution of socia movement influence. Available at SSRN 2746274.

Cavallo, A., Ghezzi, A., \& Balocco, R. (2018). Entrepreneurial ecosystem research: Present debates and future directions. International Entrepreneurship and Management Journal, 1-24.

Davis, G. F., \& Thompson, A. T. (1994). A social movement perspective on corporate control. Administrative Science Quarterly, $39,141-173$.

De Jong, J. P., \& De Bruijn, E. (2013). Innovation lessons from 3-D printing. MIT Sloan Management Review, $54(2), 43$. 
Delbridge, R., \& Edwards, T. (2008). Challenging conventions: Roles and processes in non-isomorphic institutional change. Human Relations, 61(3), 299-325.

Earl, N. (2017). 3D printing and the open source movement. https://maas.museum/inside-the-collection/2017/09/26/3dprinting-and-the-open-source-movement/.

Frederiksen, L., Dahlander, L., \& Autio, E. (2008, June). User entrepreneurship in online communities: lead user characteristics, agenda shaping and social standing. In DRUID Conference Paper.

Eliasson, G. (2000). Industrial policy, competence blocs and the role of science in economic development. Research Policy, 10, 217-241.

Emmino, N., 2012. How 3D printing is building our world. , pp.1-3. https:/www.electronicproducts.com/Packaging_and_ Hardware/Prototyping_Tools_Equipment_Services/How_3D_printing_is_building_our_world.aspx.

Eyerman, R. \& Jamison, A. (1991). Social movements: A cognitive approach. University Park, Pennsylvania: Penn State Press.

Felin, T., \& Zenger, T. R. (2009). Entrepreneurs as theorists: on the origins of collective beliefs and novel strategies. Strategic Entrepreneurship Journal, 3(2), 127-146.

Ferriani, S., Garnsey, E., \& Probert, D. (2008). Sustaining breakthrough innovation in large established firms: learning traps and counteracting strategies. In Creating Wealth from Knowledge: Meeting the Innovation Challenge. Edward Elgar UK.

Forbes, D. P., \& Kirsch, D. A. (2011). The study of emerging industries: Recognizing and responding to some central problems. Journal of Business Venturing, 26 (5), 589-602.

Gartner, W., \& Birley, S. (2002). Introduction to the special issue on qualitative methods in entrepreneurship research. Journal of Business Venturing, 17, 387-395.

Garud, R., \& Karnøe, P. (2003). Bricolage versus breakthrough: distributed and embedded agency in technology entrepreneurship. Research policy, 32(2), 277-300.

Gentles, S. J., Charles, C., Ploeg, J., \& McKibbon, K. A. (2015). Sampling in qualitative research: Insights from an overview of the methods literature. The Qualitative Report, 20(11), 1772-1789.

Gill, P., Stewart, K., Treasure, E., \& Chadwick,B. (2008). Methods of data collection in qualitative research: Interviews and focus groups. British Dental Journal, 204(6),291-295.

Gioia, D. A., Corley, K. G., \& Hamilton, A. L. (2013). Seeking qualitative rigor in inductive research: Notes on the Gioia methodology. Organizational Research Methods, 16(1), 15-31.

Golafshani, N. (2003). Understanding reliability and validity in qualitative research. The Qualitative Report, 8(4), 597-607.

Goss, D., \& Sadler-Smith, E. (2018). Opportunity creation: Entrepreneurial agency, interaction, and affect. Strategic Entrepreneurship Journal, 12(2), 219-236.

Granovetter, M. (1978). Threshold models of collective behavior. American Journal of Sociology, 83(6), 1420-1443.

Granovetter, M., \& Song, R. (1983). Threshold models of diffusion and collective behavior. Journal of Mathematical Sociology, 9, $165-177$.

Granovetter, M., \& Song, R. (1986). Threshold models of interpersonal effects in consumer demand. Journal of Economic Behavior and Organization, 7, 83-99.

Gustafsson, R., Jääskeläinen, M., Maula, M., \& Uotila, J. (2016). Emergence of industries: A review and future directions. International Journal of Management Reviews, 18, 28-50.

Heater, B. (2014). Manufacturing the future: How 3D printing went from pipe dream to your desktop. pp.1-8. https://www. digitaltrends.com/features/manufacturing-future-strange-past-impossible-future-3d-printing/. Accessed 13 June 2016.

Hoeken, Z., 2012. MakerBot vs. Open source - a founder perspective. http://www.hoektronics.com/2012/09/21/makerbot-andopen-source-a-founder-perspective/. Accessed 13 June 2016

Holzmann, P. B., Soomro, R. J., Aqeel, A., \& Schwarz, E. J. (2017). User entrepreneur business models in 3D printing. Journal of Manufacturing Technology Management, 28(1), 75-94.

Isenberg, D. J. (2011) Introducing the entrepreneurship ecosystem: Four defining characteristics. Forbes. Available at: http:// www.forbes.com/sites/danisenberg/2011/05/25/introducing-the-entrepreneurshipecosystem-four-defining-characteristics/

Jennings, P. D., Greenwood, R., Lounsbury, M. D., \& Suddaby, R. (2013). Institutions, entrepreneurs, and communities: A special issue on entrepreneurship. Journal of Business Venturing, 28(1), 1-9.

Jenkins, C. (1983). Resource mobilization theory and the study of social movements. Annual Review of Sociology, 9, 527-553.

Johnson, E. W. (2008). Social movement size, organizational diversity and the making of federal law. Social Forces, 86(3), 967-993.

Klandermans, B., \& Oegema, D. (1987). Potentials, networks, motivations, and barriers: Steps towards participation in social movements. American sociological review, 519-531.

Klepper, S. (1997). Industry life cycles. Industrial and corporate change, 6(1), 145-182.

Kira, (2015). 3D Printing Year in Review: The Biggest 3D Printing News Stories of 2015. http://www.3ders.org/articles/2015123 0-3d-printing-year-in-review-the-biggest-3d-printing-news-stories-of-2015.html.

Kirsch, D., Moeen, M., \& Wadhwani, R.D. (2014). Historicism and industry emergence: Industry knowledge from pre-emergence to stylized fact. Organizations in time: History, theory, methods, 217.

Kuzel, A. (1992). Sampling in qualitative inquiry. In F. C. Benjamin \& M. L. William (Eds.), Doing qualitative research, Sage (pp. 31-44). Thousand Oaks, CA: Sage.

Lounsbury, M., \& Crumley, L. T. (2007). New practice creation: An institutional perspective on innovation. Organization Studies, 28, 993-1012.

Lounsbury, M., Ventresca, M., \& Hirsch, P. M. (2003). Social movements, field frames and industry emergence: A culturalpolitical perspective on US recycling. Socio-Economic Review, 1, 71-104.

MacCarthy, J., \& Zald, M. (1987). The trend of social movements in America: Professionalization and resource mobilization. Morristown: General Learning Press.

Marshall, M. N. (1996). Sampling for qualitative research Sample size. Family Practice, 13(6), 522-525.

McAdam, D. (1986). Recruitment to high-risk activism: The case of freedom summer. American Journal of Sociology, 92(1), 64-90.

Mezias, S. J., \& Kuperman, J. C. (2001). The community dynamics of entrepreneurship: The birth of the American film industry, 1895-1929. Journal of Business Venturing, 16(3), 209.

Miles, M., \& Huberman, A. (1994). Qualitative data analysis (2nd edition). Sage Publications Inc. 
Miles, M., Huberman, A., \& Saldaña, J. (2014). Qualitative Data Analysis: A method sourcebook. (3rd Edition). Sage Publications Inc.

O'Shea, G., Farny, S., \& Hakala, H. (2019). The buzz before business: A design science study of a sustainable entrepreneurial ecosystem. Small Business Economics, 1-24.

Oghazi, P., \& Mostaghel, R. (2018). Circular business model challenges and lessons learned—An industrial perspective. Sustainability, 10(3), 739

Oliver, P. E., \& Marwell, G. (1988). The paradox of group size in collective action: A theory of the critical mass. II. American Sociological Review, 53, 1-8.

Pacheco, D., \& Dean, T. J. (2015). Firm response to social movement pressure: A competitive dynamics perspective. Strategic Management Journal, 36, 1093-1104.

Pacheco, D., York, J., \& Hargrave, T. J. (2014). The co-evolution of industries, social movements and institutions: Wind power in the United States. Organization Science, 8246(425), 1-50.

Patton, M. Q. (2015). Qualitative evaluation and research methods. Thousand Oaks, CA: Sage.

Pratt, M. G. (2009). For the lack of a boilerplate: Tips on writing up (and reviewing) qualitative research. Academy of Management Journal, 52(5), 856-862.

Rao, H. (1998). Caveat emptor: The construction of nonprofit consumer watchdog organizations. American Journal of Sociology, 103(4), 912-961.

Rao, H., Monin, P., \& Durand, R. (2003). Institutional change in Toque Ville: Nouvelle cuisine as an identity movement in French gastronomy. The American Journal of Sociology, 108(4), 795-843.

Rao, H., Morrill, C., \& Zald, M. (2000). Power plays: how social movements and collective action create new organizational forms. Research in Organizational Behavior, 22, 237-281.

Reynolds, P. D. (1991). Sociology and entrepreneurship: Concepts and contributions. Entrepreneurship Theory and Practice, $16(2), 47-70$.

Ritchie, J., Spencer, L., \& O'Conner, W. (2003). Carrying out Qualitative Analysis- In Ritchie, J., \& Lewis, J. (Ed.), Qualitative research practice: A guide for social science students and researchers (pp.219-62).. London: Sage Publications.

Rubin, H. J., \& Rubin, I. S. (1995). Qualitative interviewing: The art of hearing data. Thousand Oaks, CA: Sage.

Sandell, R. (1999). Organizational life abroad the moving bandwagons: A network analysis of dropouts from a Swedish temperance organization 1896-1937. ACTA Sociologica, 42, 1-15.

Schneiberg, M., King, M., \& Smith, T. (2008). Social movements and organizational form: Cooperative alternatives to corporations in the American insurance, dairy, and grain industries. American Sociological Review, 73(4), 635-667.

Schneiberg, M., \& Lounsbury, M. (2008). Social movements and institutional analysis. In R. Greenwood, C. Oliver, K. Sahlin, \& R. Suddaby (Eds.), Handbook of organizational institutionalism (pp. 650-672). London: Sage.

Schoonhoven, C.B., \& Romanelli, E. (2001). The entrepreneurship dynamic: Origins of entrepreneurship and the evolution of industries. Stanford University Press.

Shah, S. K., \& Tripsas, M. (2007). The accidental entrepreneur: the emergent and collective process of user entrepreneurship. Strategic Entrepreneurship Journal, 1(1-2), 123-140.

Sine, W. \& David, R. (2002). Environmental jolts, institutional change, and the creation of entrepreneurial opportunity in the U.S. electric power industry. Research Policy, 32, 185-207.

Sine, W. D., \& David, R. J. (2010). Institutions and entrepreneurship. Research in the Sociology of Work, 21(1), 1-26.

Sine, W. D., \& Lee, B. (2009). Tilting at windmills? The environmental movement and the emergence of the U.S. wind energy sector. Administrative Science Quarterly, 54, 123-155.

Soule, S. A. (2012). Social movements and markets, industries, and firms. Organization Studies,33(12), 1715-1733.

Spigel, B., \& Harrison, R., 2018. Toward a process theory of entrepreneurial ecosystems. Strategic Entrepreneurship Journal, 12(1), 151-168.

Stam, E., \& Spigel, B. (2017). Entrepreneurial ecosystems. In D. De Clercq, J. Heinonen, \& Z. Wang (Eds.), Handbook for Entrepreneurship and Small Business (pp. 407-422). London: Sage.

Strauss, A., \& Corbin, J. (1990). Basics of qualitative research: Grounded theory procedures and techniques. Newbury Park, Calif: Sage Publications.

Strauss, A., \& Corbin, J. (1998). Basics of qualitative research: Techniques and procedures for developing grounded theory (2nd ed.). Sage Publications, Thousand Oaks, US.

Sussan, F., Acs, Z. (2017). The digital entrepreneurial ecosystem. Small Business Economics, 49, 55-73,

Swaminathan, A., \& Wade, J. B. (2001). Social movement theory and the evolution of new organizational forms. Schoonhoven, B. C, Romanelli, E. eds. The entrepreneurship dynamic (pp. 286-313). Stanford: Stanford University Press.

Tarrow, S. (1998). Fishnets, internets, and catnets: Globalization and transnational collective action. Challenging authority: The historical study of contentious politics, 228-244.

Van de Ven, A. H. (1993a). A community perspective on the emergence of innovations. Journal of Engineering and Technology Management, 10, 23-51.

Van de Ven, A. H. (1993b). The development of an infrastructure for entrepreneurship. Journal of Business Venturing, $8(3), 211-230$.

Van de Ven, A. H., \& Garud, R. (1994). The coevolution of technical and institutional events in the development of an innovation. In J. Baum \& J. Singh (Eds.), Evolutionary Dynamics of Organizations (pp. 425-443). Oxford University Press: New York.

Van Maanen, J. (1979). The Fact of Fiction in Organizational Ethnography. Administrative Science Quarterly, 24(4).

Van Wijk, A., \& Van Wijk, I. (2015). 3D printing with biomaterials: Towards a sustainable and circular economy. Netherlands: IOS PRESS.

Van Dyke, N. and Amos, B., (2017). Social movement coalitions: Formation, longevity, and success. Sociology Compass, 11(7), 12489.

Walker, E. T. (2012). Social movements, organizations, and fields: A decade of theoretical integration.Contemporary. Sociology, 41(5), 576-587.

Weber, K., Heinze, K. L., \& DeSoucey, M. (2008). Forage for thought: Mobilizing codes in the movement for grass-fed meat and dairy products. Administrative Science Quarterly, 53(3), 529-567. 
Weber, K., \& King, B. (2014). Social movement theory and organization studies. In A. Paul, P. Du Gay, G. Morgan, \& M. I. Reed (Eds.), The Oxford handbook of sociology, social theory, and organization studies: Contemporary currents. USA: Oxford University Press.

Welter, F. (2011). Contextualizing entrepreneurship - Conceptual challenges and ways forward. Entrepreneurship Theory and Practice, 35, 165-184.

West, J., \& Kuk, G. (2016). The complementarity of openness: How MakerBot leveraged Thingiverse in 3D printing. Technological Forecasting and Social Change, 102, 169-181.

Wohlers, T.,2003. Will the A/E/C Industry Adopt RP? https://wohlersassociates.com/blog/2003/05/will-the-aec-industry-adopt-rp/. Yin, R. K. (2003). Case study research: Design and methods. Thousand Oaks, CA: Sage.

Yin, R. K. (2011). Qualitative research from start to finish. New York: The Guilford Press.

Zahra, S. A. (2007). Contextualizing theory building in entrepreneurship research. Journal of Business Venturing, $22,443-452$.

Zahra, S. A., Wright, M., \& Abdelgawad, S. G. (2014). Contextualization and the advancement of entrepreneurship research. International Small Business Journal, 32, 479-500.

\section{Publisher's Note}

Springer Nature remains neutral with regard to jurisdictional claims in published maps and institutional affiliations.

Submit your manuscript to a SpringerOpen ${ }^{\odot}$ journal and benefit from:

- Convenient online submission

Rigorous peer review

- Open access: articles freely available online

High visibility within the field

- Retaining the copyright to your article

Submit your next manuscript at $\boldsymbol{\nabla}$ springeropen.com 